\title{
The whence and whither of marine spatial planning: revisiting the social reconstruction of the marine environment in the UK
}

\author{
Heather Ritchie ${ }^{1}$ (D) $\cdot$ Linda McElduff ${ }^{1}$
}

Received: 30 August 2019 / Accepted: 20 February 2020 / Published online: 30 April 2020

(C) The Author(s) 2020

\begin{abstract}
With the concept of marine spatial planning (MSP) firmly established in the UK with its own legislation, policies and plans underway, this paper critically revisits MSP as part of the wider debate associated with the social reconstruction of the marine environment, as first discussed by Peel and Lloyd's seminal paper in 2004. We propose that their identified 'marine problem' remains and indeed has exacerbated. We ascertain that there has been much change in the governance of the marine environment that has both positively and negatively altered the way that society has (re)constructed solutions to that marine problem. We revisit Hannigan's (1995) social constructionist framework, showing the degree to which the prerequisites have been satisfied, by providing an overview of how the marine problem has intensified in the preceding 15 years and how the marine problem has now captured the wider public's attention. We then look at the how the response to the marine problem has evolved by examining at the current marine planning arrangements across the UK. We conclude by stating that the whence of MSP is clear, culminating with the formal introduction of MSP in the UK which has positively altered the way in which the marine environment is socially reconstructed. The whither is much more unclear. With a continually rapidly moving agenda of change, there is much more to be done for us to say that the marine problem has been successfully socially reconstructed.
\end{abstract}

Keywords Marine spatial planning $\cdot$ Social reconstruction $\cdot$ Marine problem $\cdot$ Marine governance

\section{Introduction}

The UK marine area extends some $867,400 \mathrm{~km}^{2}, 3.5$ times the UK terrestrial area (Russell 2010, Brown et al. 2011); it is an area of high ecological importance and natural resources. The UK marine biodiversity is estimated to be worth $£ 2670$ billion (2017, Government Office for Science). The economic aspects of the marine environment is often lost, as the Wildlife Trusts (2019) 'Living Seas' project highlighted the disconnect between everyday human activities and the long-term impact of these activities on the marine environment. Increasing

This article is part of the Topical Collection on Critical turn in Marine Spatial Planning - whence and whither?

Heather Ritchie

h.ritchie@ulster.ac.uk

Linda McElduff

1.mcelduff@ulster.ac.uk

1 Belfast School of Architecture and the Built Environment, Ulster University, Newtownabbey, UK awareness of our marine environment is critical to protecting our seas, especially at the coast which is now becoming increasingly urbanised, even industrialised (Flannery et al. 2018). As Ritchie and Ellis (2010) noted, the growing intensity of marine-related activities, accompanied by the economic contributions it brings, has had severe negative consequences for the marine environments ecological and physical conditions. Indeed, Allsopp (2007) suggested that in the absence of an effective system of sustainable management, the seas are headed for an imminent crisis. The disjointed regulation of marine activities and the associated cumulative and conflicting pressures have led to a lack of strategic and integrated spatial management. Taking these issues cumulatively, this may be characterised as the 'marine problem'. We are concerned with the evolving awareness of the marine problem within the general public, and as such, the social reconstruction of that problem and to consider if it has captured the wider public attention.

Peel and Lloyd (2004) noted that the marine environment faces a complex mix of ownership and property rights. It also faced inappropriate, piecemeal and ad hoc silo mentality management for a diverse range of activities in marine, coastal, 
intertidal and onshore territories, of which MSP was hoped to holistically integrate and facilitate particular economic activities (Jay 2010). Many early initiatives (pre-2000s) at that time were sectorally led and driven by short-term economic gain and the use of scientific evidence was partial. Consequently, a fully integrated understanding of the marine environment was lacking (Peel and Lloyd 2004; Scottish Executive 2002).

Much of the literature in the early twenty-first century highlighted the impetus towards the creation of a new institutional framework for the marine environment to improve coordination, overcome sectoral fragmentation and address policy duplication (see now older, references for example Bull and Laffoley 2003; Canning 2003; Tyldesley 2004). Ritchie and Ellis (2010) further identified two key strands to the marine problem, set within a much broader and varied context of contributing factors. On the one hand, the perception of the 'marine problem' may be essentially an 'environmental one', while on the other hand, others perceived the prime cause to be lying within the 'institutional fragmentation' governing the management and regulation of the seas. We pose that there could be an additional, more societal strand of the marine problem, in terms of recognition of a lack of 'marine stewardship'. Still today, we find that, while improved, there is limited appreciation of the marine problem Ritchie (2014) and we inquire why this is the case and what policy interventions have been put in place.

This paper critically considers the whence and whither of marine spatial planning (MSP) in the UK over the 15-year period since Peel and Lloyd's (2004) seminal paper. In 2004, there was little understanding of MSP as a concept since it was considered in its infancy compared with its 'land-based cousin': Land Use Planning. At that time, it was suggested that an incremental extension of land-based controls over the aspects of the marine environment may have been the solution to an environmental and institutional marine problem. The formal introduction of a system of MSP, a form of policy intervention to the marine environment, through the Marine and Coastal Access Act 2009, is one of the biggest contemporary environmental challenges that has faced the state (and society) since the introduction of the Land Use Planning Act 1947. What Russ and Zeller (2003) referred to as Mare Liberum is now subject to rigorous state controls. MSP has since become the dominant marine management paradigm (Flannery and Ellis 2016; Kidd and Ellis 2012) in Europe and mostly clearly in the UK, yet the context within which it is maturing has changed dramatically from that anticipated in the early 2000s.

This paper revisits what is meant by the marine problem and how this has evolved over the last 15 years. In doing so, we identify the key drivers behind such change and how perceptions of the marine environment have been socially constructed, altered and shaped by various 'prerequisites'. This is achieved by following, as Peel and Lloyd (2004) did, Hannigan's (1995) framework for the social construction of an environmental problem. This framework provides useful insights into "the processes by which an issue can successfully obtain public attention [...] foster and sustain public debate, leading to broader societal understanding and action" (Peel and Lloyd 2004). Advancing the 2004 paper in this way provides the context for exploring the legislation, policies and plans emerging across the UK, as MSP moves from infancy to adolescence. This investigation helps to address the 'whence' of MSP in terms of how such an environmental issue has come to the fore in a societal agenda, and in addressing the 'whither', we forecast where MSP takes it next critical turn as the UK system continues to mature in uncertain times within an ever accelerating agenda of change.

\section{The social reconstruction of the marine problem: revisiting Hannigan's prerequisites}

Peel and Lloyd (2004) used Hannigan's theoretical framework to trace the evolution of thinking towards marine spatial planning in the UK. While not discussed in detail in this paper, social constructionism is often contested and misunderstood (see for example Jones 2002). A social constructionist approach is characterised by 'a critical stance towards takenfor-granted knowledge' and challenges the view 'that conventional knowledge is based upon objective, unbiased observation of the world' (Burr 2003, p.3). Rather, humans 'construct' knowledge as opposed to find or discover it (Schwandt 2000) and sustain knowledge through social processes. Societal interactions between groups and individuals are thus fundamental to the development of knowledge and meaning.

The primary focus of the social constructionist approach is in examining the "social, political and cultural processes by which certain environmental conditions are defined as unacceptably risky, and therefore, contributory to the creation of a perceived "state of crisis"' (Hannigan 2006, p.29). For instance, although the power of nature is not denied, its impacts at a given point in time are open to interpretation, as is the "rank ordering of environmental problem claims [which do not] always correspond to actual need [but reflect] the political nature of agenda setting" (Hannigan 2006, p.31). Following Hannigan (2006, p.63), a social constructionist approach to environmental problems acknowledges that issues:

do not rise and fall according to some fixed, asocial, self-evident set of criteria, but are related to successful 'claims-making' by a cast of social actors that includes scientists, industrialists, politicians, civil servants, journalists and environmental activists.

Consequently, Hannigan (2006) identified six prerequisites for the successful construction of an environmental problem: 
- Scientific authority for and validation of the claims;

- Existence of 'popularisers' to bridge environmentalism and science;

- Media attention to 'frame' the problem as novel and important;

- Dramatisation of the problem in symbolic and visual terms;

- Economic incentives for encouraging positive action;

- Institutional sponsor(s) to provide legitimacy and continuity.

Peel and Lloyd (2004) used these six prerequisites to structure their discussion on the 'reconstruction' of the 'marine problem', against the emergence of MSP in UK and European contexts. In doing so, the framework provided useful insights into 'the processes by which an issue can successfully obtain public attention [...] foster and sustain public debate, leading to broader societal understanding and action' (2004, p.363). For Peel and Lloyd (2004), the prerequisites follow 'a relatively linear process of recognition, evaluation, reflection and action'. Yet, the categories are invariably mutually dependent if a problem is to be successfully constructed and acted upon (McClelland 2014).

Put succinctly, Hannigan's framework provides a useful tool in helping to explain why environmental issues come to the fore, how they might gain identity and momentum on the policy agenda, and provides understanding and opportunities for understanding, reflection and invoking action. Ultimately, it is about how society recognises a specific environmental issue as a problem and how this invokes subsequent active engagement by society and the ways in which intervention can be formed (Peel and Lloyd 2004). Examples can be found across the UK, including the smoking ban in public places (Anyanwu et al. 2018) and the plastic bag levy (Ferreira et al. 2007), and perhaps even veganism (Greenebaum 2015; Lundahl 2018). In regard to the marine environment, marine plastics (Derraik 2002, Pahl et al. 2017; Thompson 2017; Xanthos and Walker 2017) and marine litter have become increasingly recognised as problems requiring immediate action, potentially at the expense of other ongoing problems, or dealing with the need for more radical changes to behaviour and economic systems to address large environmental issues, such as plastic pollution through over consumption (Stafford and Jones 2019).

While the 'marine problem' is perhaps now more pronounced, we question, using the six prerequisites, whether it has reached the wider public's attention. There appears to be limited appreciation and recognition for action: i.e. what is MSP seeking to respond to? MSP is posed as the appropriate solution, set to provide the joined up, holistic approach to sustainable management of our seas. As part of that solution, it is crucial some credence is paid to the Marine Strategy Framework Directive European Commission (2008a), as
Gilbert et al. (2015) note that the required good environmental status maybe achieved as MSP emerges to be the tool that rationalises competing uses. However, it needs action (through policy intervention) to allow for this sustainable approach to be employed. Following Hannigan's framework, the following sections revisit and build upon the marine problem 15 years on. This investigation allows us to identify new perceptions of how marine problem has been further intensified, exacerbated and evolved since the early 2000 s.

\section{Scientific authority}

For claims over an environmental condition to be successfully transformed into a problem demanding action, there needs to be the presence of scientific authority. In this regard, a body of validating evidence from the life or physical sciences has traditionally been deemed as particularly important. Peel and Lloyd (2004) pointed to the early conferences of the 5th North Sea Conference and the work of DEFRA (Department of Environment, Food and Rural Affairs) (2001) Safeguarding our Seas which set the vision and strategic goals to state within one generation we want to make a real difference to how the marine environment is managed. It pledged to adopt an ecosystem-based approach to marine management focused on research and making effective use of existing scientific knowledge and advice in policy-making. Linked to this was the Irish Sea Pilot Report to DEFRA by the "Joint Nature Conservation Committee" in 2002 which noted (p.23) 'The result ${ }^{1}$ has been the over-exploitation of many fish stocks to a degree which is highly deleterious both to sustainable fishing and to the environment'. A WWF (World Wildlife Fund) report (WWF 2002) claimed that global cod catch suffered a $70 \%$ drop over 30 years and stated that cod stocks could be wiped out in less than a generation because of overfishing, shipping and oil exploitation. Two years later, the Telegraph's headline on the 13th of May 2004, 'Cod stocks could be wiped out' certainly grabbed the public's attention.

Since then, there have been an increasing volume of scientific documents and prestigious conferences at international, national and local scales. One of the most pertinent ones is the UN Climate Change Paris Conference 2015; United Nations (2015) which stated:

Oceans have warmed, the amounts of snow and ice have diminished and the sea level has risen. From 1901 to 2010, the global average sea level rose by $19 \mathrm{~cm}$ as oceans expanded due to warming and ice melted. The sea ice extent in the Arctic has shrunk in every successive decade since 1979 , with $1.07 \times 106 \mathrm{~km}^{2}$ of ice loss per decade.

\footnotetext{
${ }^{1}$ Of the use of EC funds to increase the efficiency of the European Union's fishing industry
} 
Similar trends are seen across the devolved administrations of the UK. For example in the Department of Agriculture, Environment and Rural Affairs' (DAERA) Northern Ireland Environmental Statistics Report (2018a) identified multiple ways that Northern Irish waters are not on track for the posited 'Good Environmental Status' MSFD, European Commission (2008a) by 2020 . Under the Water Framework Directive (WFD) monitoring, 16 out of 25 water bodies were at 'moderate', 'poor' or 'bad' status in transitional and coastal waters. Additionally, only $4.48 \%$ of Northern Ireland's protected marine area is considered by Marine Division to be under 'favourable' management and there has been a decreasing trend since 2009/10, although the area designated has increased. The most recent 2019 report headline statistics show no improvements: beach litter has increased from 2016/17 levels (up 1800 items per sq $/ \mathrm{km}$ ) and no change with still only $4.48 \%$ of the marine area remaining under favourable management (DAERA 2018b).

Despite the emphasis upon marine science, Peel and Lloyd (2004) argued that there is no real consensus on the nature of the marine problem or on how it 'should' be addressed due to the complexity of the marine environment and the presence of conflicting interests, rules and property rights. Traditionally, the idea of 'scientific authority' in the marine environment has tended to come from a highly technocratic, rational approach to defining problems. Interestingly, more recent times have witnessed the rise of 'marine social science' as an equally critical and robust body of knowledge and scientific authority (Bennett 2019; Shah 2020). In 2018, a new Marine Social Sciences Network ${ }^{2}$ was launched with the intention of facilitating knowledge exchange and increasing awareness and understanding of the role of social sciences in coastal-marine management and decision making. This suggests new arenas of exploration and debate, incorporating marine social and natural science, the arts, culture and humanities, are developing more complete understandings of the marine environment, feeding into policy and political agendas and in turn shaping societal perceptions. The interpretation of such varied evidence requires the use of one or more of Hannigan's other prerequisites to translate this information into a claim for the problem.

\section{Popularisers in the marine environment}

The second prerequisite is the existence of popularisers who are able to successfully transform a complex issue into a proactive claim (Hannigan 2006). These 'popularisers' can range from scientists or experts in a field related to the claims being made, to activists or concerned environmentalists from a diversity of backgrounds. In 2004, Peel and Lloyd (2004)

$\overline{{ }^{2} \text { See www.marsocsci.net }}$ highlighted the role of organisations such as the WWF and Greenpeace, in promoting issues in the public eye, drawing attention to (real or perceived) weaknesses in prevailing institutional, legislative and policy arrangements and prompting reconsideration of the appropriate intervention required. The key task of popularisers, thus, is to campaign on an issue in a manner that garners public support and bolsters appeals to policy-makers and politicians for action. They often seek to bridge environmentalism and science, perpetuate a focus of attention on the issue and sustain public interest of the problem. WWF, Friends of the Earth and Greenpeace remain important popularisers but new entities, focusing specifically on the coastal and marine environment have also emerged more recently at a variety of scales (Table 1 ).

The growth of these organisations, at multiple scales, demonstrates a rise in public awareness of the need to address the problems facing the marine environment. Interestingly, these entities, and others, are beginning to focus their campaigns on marine plastics and marine pollution demonstrating how certain issues can come to the fore and dominate the discourse at a given time. For example, the Centre for Biological Diversity (CBD 2019) notes that the ocean plastics pollution is a 'global tragedy' for our oceans and sea life. The plastic accumulating in our oceans and beaches has become a global crisis. Billions of pounds of plastic can be found swirling in convergences that make up $40 \%$ of the world's ocean surfaces (Earth's Oceans Foundation 2019). Geyer et al. (2017) note that if the current production and waste management issues continue, roughly 12,000 million tonnes of plastic waste will be in landfills or in the natural environment by 2050 . The presentation of these facts and comparisons demonstrates the role of dramatisation of the issue.

\section{Dramatisation of the marine problem}

The need for media attention and the dramatisation of a particular problem in symbolic and visual terms are closely related to the popularisers and all three are often considered together. Media attention is crucial in bringing the issue to the attention of the public, as changes in policies and/or political priorities are unlikely in the absence of an outpouring of public opinion (McClelland 2014). Media attention in itself, however, is insufficient in terms of mobilising and sustaining interest in a problem. The problem must be communicated in a manner that makes it both 'real and important' for the general public (Hannigan 2006, p.77). Moreover, the use of evocative language and visual imagery is an important aspect in commanding of public attention and the dramatisation of a problem. Importantly, it should also be noted that competing interests are likely to engage with the media in counter-rhetorical and other strategies (Ibarra and Kitsuse 1993). 
Table 1 Examples of popularisers working in the marine environment

\begin{tabular}{|c|c|c|}
\hline Scale & Initiative/project & Overview \\
\hline \multirow[t]{2}{*}{ Global } & Plastic Oceans International & $\begin{array}{l}\text { A global non-profit organization that addresses the issue of plastic } \\
\text { pollution and how it impacts our waters, sea life and humans. }\end{array}$ \\
\hline & Whale and Dolphin Conservation & The leading charity dedicated to the protection of whales and dolphins. \\
\hline \multirow[t]{2}{*}{ National } & Surfers Against Sewage & $\begin{array}{l}\text { Grassroots movement tackling plastic pollution and protecting the } \\
\text { UK's coastlines for all to enjoy safely and sustainably. }\end{array}$ \\
\hline & Marine Conservation Society & $\begin{array}{l}\text { The UK's leading marine charity working to ensure our seas } \\
\text { are healthy, pollution free and protected. }\end{array}$ \\
\hline Regional & Northern Ireland Marine Task Force & $\begin{array}{l}\text { A coalition of ten environmental non-government organisations - } \\
\text { campaigning for comprehensive marine legislation and policy } \\
\text { to safeguard our coastal and marine wildlife and ensure } \\
\text { sustainable use of our seas. }\end{array}$ \\
\hline \multirow[t]{2}{*}{ Local } & $\begin{array}{l}\text { Keep Northern Ireland Beautiful - } \\
\text { Clean Coasts Programme }\end{array}$ & $\begin{array}{l}\text { Volunteers sponsored by Coca Cola to carry out practical and } \\
\text { innovative projects (such as Beach clean boot camp + extreme } \\
\text { cave clean) to reduce impact of beach litter. }\end{array}$ \\
\hline & $\begin{array}{l}\text { Beach Cleaners - Ards and } \\
\text { North Down Group }\end{array}$ & $\begin{array}{l}\text { Volunteers groups organizing participation in initiatives } \\
\text { such as \#2minutebeachclean and \#take3 forthesea. }\end{array}$ \\
\hline
\end{tabular}

The dramatisation of marine issues has been on the rise since the early 2000s. The general publics' awareness of marine issues has happened, almost subliminally, through the dramatization created through television documentaries. Documentaries can be powerful, shocking and heartbreaking and aim to educate viewers to learn more about the world they live in, from their armchair. In relation to the early dramatisation of the marine environment in 2004, Peel and Lloyd highlighted the role of Greenpeace and Friends of the Earth as 'popularisers', who had dramatic images for overfishing, pollution and 'ghost ships'. The rise of the celebrity-fronted documentary and celebrity endorsed causes (Erdogan 1999, Boykoff and Goodman 2009; Anderson 2013) has been no doubt instrumental in bringing various environmental issues to the attention of general public. In relation to marine issues, the UK celebrity chef Hugh Fearnly-Whittingstall's (2010) 'Fish Fight' campaign in 2010 brought the consequences of the fisheries discard ban to the attention of the general public (Fearnly-Whittingstall 2010). The campaign highlighted that in some cases, $50 \%$ of edible fish in the North Sea were being thrown back into the water. This initial documentary became a TV series and received 875,000 signatures on an online petition to call for changes to the Common Fisheries Policy (which succeeded). This was the first of many types of programmes and campaigns designed to raise public awareness of the environmental issues in our oceans. As a result, sales of sustainable seafood rose in UK supermarkets as reported by Sainsbury's ${ }^{3}$ in 2011.

Of particular note is Sir David Attenborough's award winning TV mini-series 'Blue Planet II' which was the most

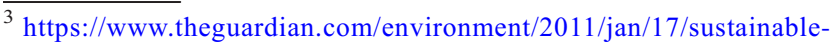
seafood-supermarkets-fish-fight
}

watched British TV programme of 2017 (topping the polls at 14.01 million) and averaging 10.3 million viewers on a Sunday night. At the end of the series, there was some reflection on mankind's influence on the world's oceans through global marine pollution and climate change. It had an important message on marine plastic with powerful clips showing the effects of marine plastic on marine mammals. As Monbiot (2018) says, these programmes demonstrate a vast public appetite for information about the environmental crisis and an urgent desire to act on it. Yet he criticised the programme saying it downplayed the environmental crisis and it generated complacency, confusion and ignorance.

Following the global impact of the programme, Sir David Attenborough is now involved in the BBC's initiative 'Plastics Watch' which is inspiring people to reduce single use plastic. The strength of the campaign has resulted in 40 food and drinks companies in Britain to cut plastic pollution in an effort to reduce the 8 million tonnes of plastic that ends up in the oceans every year. Social media appears to have played a significant part in the campaign with @BBCEarth's \#OurBluePlanet and \#BluePlanet2 reaching 37 million people. The 'Attenborough effect' is causing plastic pollution to decrease with Global Citizen (2019) reporting single use plastic reducing. Following on from the 'Attenborough effect'; in 2018, the (then) UK Prime Minister, Theresa May, created a $£ 64.1 \mathrm{~m}$ fund to fight plastic pollution and called upon the 52 commonwealth leaders to sign up to the 'Commonwealth Clean Oceans Alliance', noting that it is one of the most significant environmental challenges facing the world today. Of the funding pot, $£ 25 \mathrm{~m}$ will go towards scientific research on plastic, $£ 20 \mathrm{~m}$ will be used to curb plastic pollution generated by the manufacturing and the remaining $£ 19.9$ m will be devoted to improving waste management. 
The growth of social media is one of the biggest changes since Peel and Lloyd's study. The advent of social media outlets Twitter/Facebook/Instagram/Snapchat has no doubt had an impact on raising the profile of environmental and social issues (Krau and Chahal 2018; Kratzig and WarrenKretzscmer 2014). These platform tools are gaining importance in increasing environmental concern and environmentally responsible behaviour in public (Kratzig and WarrenKretzscmer 2014). As Krau and Chahal (2018) note, social media can be used as an enabler to create new awareness of environmental issues. This is in stark contrast to 2004 where there was a tendency for the media to only present exotic images of the marine environment from overseas. People can have an emotive response to such images, of calm or delight or happiness. However, what seem to be on the increase now are images that may cause upset or distress. The conservation group Sea Shepherd released disturbingly graphic images of a turtle and seal with their heads trapped in plastic, for its campaign 'Operation Clean Waves' (Sea Shepherd 2018), which aims to create a plastic free ocean in 10 years. These powerful adverts carry the hard hitting strapline 'the plastic you use once tortures the oceans forever'.

The use of 'real' images of seashores covered in washed-up plastic and images of marine mammals being covered in or having consumed plastic is generating a more emotive response. In this regard, the importance of people-place relationships is significant as a strong attachment to place (e.g. marinecoastal environments) and concern for local socio-ecological systems (e.g. coastal communities, marine birds and animals and marine ecosystems) can mobilise community action in response to identified issues and challenges and is a contributing factor to local stewardship and voluntary activities (McElduff and Ritchie forthcoming). Greater understanding of peoples' relationship and attachment to the marine environment is required. The GAUFRE project in 2005 poignantly stated that, for years, planners all over the world have been planning with their backs to the sea (Maes et al. 2007). Perhaps citizens are now leading the turn? It has been highlighted that higher levels of involvement in the management of the marine environment can not only benefit the marine environment but also provide an increased sense of marine citizenship (McKinley and Fletcher 2010; Jefferson et al. 2015; Potts et al. 2016).

\section{Financial incentives to provide behavioural change}

The fifth prerequisite concerns the provision of financial incentives for encouraging positive action on a particular problem. Importantly, economic incentives for one group may adversely impact another and its character, rendering the marine environment vulnerable to overexploitation. This may be illustrated by the economic cost implications of degradation of fishing stocks and pollution. The marine environment has a complex set of property rights, but is largely characterised by common property regimes with international diplomacy for certain activities (such as fishing or exploration for offshore oil and gas). Incomplete specification of property rights is a major source of conflict in natural resource use. Most recently, there has been an international dispute over Rockall: an uninhabited island in the North Atlantic Ocean. The UK has claimed ownership over the rocky outcrop and the 12-nm territorial waters around it since passing the Rockall Act 1972 which formally incorporated it into the Scotland's Western Isles. On the 31st of May 2019, Scotland threatened Ireland with formal enforcement proceedings on the grounds of illegal fishing within the territorial waters. Ireland argues that Scotland is in breach of United Nations Convention on the Law of the Sea (UNCLOS 1982), which states that an exclusive economic zone or territorial waters cannot be established around an uninhabited island.

Additionally, the current terrestrial planning system and the emerging marine planning system, while legally and functionally separate, overlap in the intertidal area. Local land use plans and regional marine plans should therefore be complementary, but the extent to which this happens in practice is perceived to be limited. Across the UK, there are many different statutory rules and regulations in relation to the ownership of, and access to, the marine environment, the seabed and the intertidal area (McElduff and Ritchie forthcoming).

Since the Blue Growth Strategy (European Commission, 2012), it is reported that the seas and oceans are seen as the drivers for the European economy and are a source of achieving sustainable blue growth. The strategy calls for member states to use MSP as a tool to enhance growth and sustainability. In this 15 -year timespan, there has been a significant restructuring of marine activities and progression of technology, which is changing our behaviour in terms of how we use the marine resource. Most prominent is in the development of the offshore renewable industry: wind, wave and tidal technologies have evolved significantly, and many are now at commercialisation stages. For example, compressed air energy storage (CAES) and gas storage is now in operation under the seabed within the areas of UK, as is commercial seaweed cultivation, biotechnology and deep-sea mining. Traditional activities such as fishing and shipping have also changed. There is an increased focus on ecotourism, recreation and leisure, including cruise-liner numbers and size. In Belfast Harbour alone, a record number of $155 \times 300 \mathrm{~m}$ Cruise Liners came in 2019 bringing 250,000 visitors to Northern Ireland (Knott 2019). So even regionally, the seas and its uses have got dramatically busier. This raises major issues on how and what sort of appropriate management interventions are being put in place for tackling the marine problem. Is MSP reaching its full potential? 


\section{Emerging institutional sponsors and legislative responses}

The final prerequisite concerns the need for an institutional sponsor(s) that is willing to engage in problem-solving, particularly when policy and legislative action are required (Hannigan 2006). In relation to the marine environment, Peel and Lloyd (2004) identified a number of weaknesses and concerns in relation to the institutional context, including a lack of leadership and a demanding multiplicity of legislation, policies and priorities. They identified a range of emerging institutional sponsors including the Crown Estate, environmental organisations, governmental executive agencies and both central and local government. These entities still exist with new marine roles and responsibilities that operate at multiple scales, including an appointed marine authority for each of the four UK administrations (Table 2). Boyes and Elliot (2014) and Kelly et al. (2018) have developed 'horrendograms' to illustrate that these bodies are operating within, at least, 200 European, UK, and regional level legislative instruments. The impending exit from European Union (on 31 st January 2020) risks the situation becoming even more 'horrendous', as demonstrated by Boyes and Elliot (2016) updated 'horrendogram'. Peel and Lloyd identified a number of weaknesses and concerns in relation to the institutional context, including a lack of leadership and a demanding multiplicity of legislation, policies and priorities. Peel and Lloyd described the governance of marine environment as an 'administrative battleground' in 2004, but now it could be characterised as a marine governance 'disaster zone'.

The legislative context for the marine environment has evolved significantly since the early 2000s. At the European level, the main driver for marine legislation and policy came from the EU Parliament who adopted an Integrated Maritime Policy in 2007 (European Commission 2007) and then shortly after issued a road map for MSP in 2008 (European Commission 2008a) to ensure a common approach to maritime economic development across the EU. A timetable to achieve and maintain 'good environmental status' (GES) of EU waters by 2020 was consequently developed through the European Commission (2008b). DEFRA launched a consultation document in 2019 setting out proposals for the assessment of progress towards the achievement of GES for the UK seas (DEFRA 2019).

In the UK, since 2009, a number of legislative and policy provisions have been put in place for integrated marine management including, inter alia, the Marine and Coastal Access Act (MCAA) 2009 (for English and Welsh inshore, offshore,

Table 2 Summary of marine plan development, legislation and marine authorities

\begin{tabular}{|c|c|c|c|}
\hline & Responsible body & Key pieces of legislation & Marine plan status and progress \\
\hline England & $\begin{array}{l}\text { Marine Management } \\
\text { Organisation (MMO) }\end{array}$ & $\begin{array}{l}\text { Marine and Coastal Access Act } \\
\text { (MCAA) } 2009\end{array}$ & $\begin{array}{l}\text { Marine plans are produced at the regional scale } \\
\text { for both inshore }(0-12 \mathrm{~nm}) \text { and offshore } \\
\text { (from } 12 \mathrm{~nm} \text { to the exclusive economic } \\
\text { zone limit), with a total of } 11 \text { marine plan } \\
\text { areas identified by the MMO. Eight plans } \\
\text { are being developed in parallel with each } \\
\text { other through an iterative process due to } \\
\text { be completed in } 2020 \text {. }\end{array}$ \\
\hline Wales & Welsh Government & $\begin{array}{l}\text { MCAA } 2009 \text { Well-being of Future } \\
\text { Generations (Wales) Act } 2015 \\
\text { Environment (Wales) Act } 2016 .\end{array}$ & $\begin{array}{l}\text { The Welsh National Marine Plan was published } \\
\text { in November } 2019 .\end{array}$ \\
\hline Scotland & Marine Scotland & $\begin{array}{l}\text { MCAA } 2009 \text { Marine Act } \\
\text { (Scotland) } 2010\end{array}$ & $\begin{array}{l}\text { The Scotland National Marine Plan (2015) } \\
\text { provides single framework for managing } \\
\text { Scotland's seas. The first review process } \\
\text { has been completed. The National plan is } \\
\text { supplemented by eleven regional marine } \\
\text { plans prepared by Marine Planning } \\
\text { Partnership which provide more detailed } \\
\text { guidance for inshore waters. }\end{array}$ \\
\hline Northern Ireland & $\begin{array}{l}\text { Department of Agriculture, } \\
\text { Environment \& Rural } \\
\text { Affairs (DAERA) }\end{array}$ & $\begin{array}{l}\text { MCAA } 2009 \text { Marine Act } \\
\text { (Northern Ireland) } 2013\end{array}$ & $\begin{array}{l}\text { The draft Marine Plan for Northern Ireland was } \\
\text { published in April 2018. Since the collapse } \\
\text { of the Stormont Executive in January 2017, } \\
\text { Northern Ireland was without a government, } \\
\text { the draft plan was unable to proceed to the } \\
\text { next stage of plan adoption, due to the cross- } \\
\text { cutting nature of the marine plan. However, } \\
\text { the government was restored in January } 2020 \\
\text { and it is hoped the plan will be adopted in } \\
\text { the near future. }\end{array}$ \\
\hline
\end{tabular}


Scottish offshore and Northern Ireland offshore waters), the Marine (Scotland) Act 2010 (for Scottish inshore waters) and the Marine (Northern Ireland) Act 2013 (for Northern Irish inshore waters).

The Marine and Coastal Access Act (2009) was the UK's first piece of comprehensive legislation focused on the governance of the marine environment. The devolved administrations subsequently adopted a set of high-level marine objectives to ensure consistency in approach towards the UK government vision for the marine environment 'clean, healthy, safe, productive and biologically diverse oceans and seas' (UK Government 2009). This alignment was furthered by the UK-wide Marine Policy Statement (HM Governments 2011), which placed a statutory obligation to develop marine plans. This later became an EU statutory obligation through the Marine Spatial Planning Directive the European Commission 2014. Marine planning in the devolved administrations has to deliver the UK Marine Policy Statement (HM Governments 2011). By contrast, Scotland, Northern Ireland and Wales have executive responsibility for marine planning, wind and wave power, fishing and marine conservation, from 12 to $200 \mathrm{~nm}$, the offshore waters (abiding with the international laws, the 1982 UNCLOS and EU laws and conventions).

While each devolved administration has developed its own approach to marine planning and delivery mechanisms to reflect the specificities of their seas and local approaches to marine governance, all marine plans must be consistent with the Marine Policy Statement. The marine plans have been progressed at different times and speeds and are informed by jurisdictional priorities and legislation (see Table 2). Significant reforms of its Land Use Planning system (as detailed by Lloyd 2008).Marine authorities were established across the UK (Table 2): Marine Scotland was established as a directorate of the Scottish Government; in England the Marine Management Organisation was established as a stand-alone public body; the Welsh Government and the then DOE NI (now DAERA) were established.

The emergence of the aforementioned institutional sponsors and pieces of legislation represented an acknowledgement of the need to update the UK marine and coastal governance framework so that it could be better equipped to deal with the challenges of the twenty-first century and enable the sustainable development of the UK seas. The introduction of legislation and policy were indicative of a major, yet seemingly underappreciated, milestone in environmental regulation in the UK: a true reflection of the evolution of marine governance in the UK (Fletcher et al. 2014). The MCAA, for example, was hailed as one of the most important and longawaited pieces of UK conservation legislation. However, even though the legislation established a comprehensive regulatory planning system for the UK's marine environment, it has been heavily critiqued (Flannery and Ellis 2016). While the intention was for legislation to ensure common principles for MSP with the Scottish and Northern Irish legislation nested within and integrated with the MCAA (Hull 2015), Ritchie and Flannery (2017) argue that the UK government fell short of facilitating any integrated management of the marine resource. While the legislative structures allow for some integration for synergies between terrestrial and marine planning and licensing regimes, they argued it does not allow for a unified and simplistic approach to marine planning. This is demonstrated when we look at the functions of maritime zones (as detailed extensively by Ritchie and Flannery 2017). In summary, from the baseline (Mean High Water Mark) up to $12 \mathrm{~nm}$ is considered the inshore region; the devolved administrations have a legally separate responsibility for marine management (within the legislative functions described above). This does not include powers over navigation, oil or gas which is reserved for the UK government.

In Northern Ireland, this complex governance and legislative arena has become increasingly pronounced in recent years (Northern Ireland Office 1998). First, the lack of a Stormont executive in Northern Ireland since January 2017 has halted the progression and implementation of the Northern Ireland Draft Marine Plan (April 2018). Second, Northern Ireland has undergone significant reform of its land use planning system together with the reform of public administration (since 2015) with planning now operating at a central level in the local public authorities (which themselves have undergone significant reductions in numbers, shifting from 26 local authorities to 11 council regions). These new local planning authorities have to take into account what is happening in the marine environment, as they have a statutory obligation to take account of marine plans in making their decision. This is particularly important for renewable energy projects where the development is both offshore and onshore. Third, there are many additional pressures of the unknown consequences of the UK exiting the EU, Northern Ireland Affairs Committee (2018) but especially with Northern Ireland, with the shared border with the Republic of Ireland.

In the absence of an institutional sponsor at the EU level: DEFRA, as authors of the MCAA, and the marine plan authorities might be expected to step up to the mark (McGowan 2011). Yet, the role of NGOs (including the aforementioned: UK Marine Conservation Society, Wildlife Trusts, Greenpeace, WWF) should not be overlooked in terms of shaping and leading current debates and responses to identified marine problems. Additional institutions emerge from landownership patterns including the Crown Estate, as owner of the sea bed, and the National Trust, a major coastal landowner. We see these bodies as having a pivotal role in providing responsible stewardship. As Peel and Lloyd (2004) stated, the practice of integrated stewardship of the marine environment means reducing the reliance on regulation and entrusting the respective bodies and communities of 
interest to take responsibility. Furthermore, they highlighted that stewardship has become a target of potential policy capture for those with an interest in solving the marine problem. Caution needs to be applied to any hidden agendas of these institutional sponsors. Can the marine planning authorities really be said to be appropriate institutional sponsors when they are so clearly guided by Blue Growth Strategies under a veil of sustainable economic growth? Ritchie and Ellis (2010, p.716) called for 'system that works for the sea, not for the government administrative systems', posing the idea of creating a 'sea interest' as an overarching objective of the MSP process. Perhaps such a notion could provide an objective of calls for marine stewardship.

\section{Conclusions}

The marine problem is truly reflective of Rittle and Webber's (1973) 'wicked issue' and more recently to what Kelly et al. (2019) refer to as 'persistent problems'. Peel and Lloyd (2004) could not have predicted the evolution of MSP that has occurred over the last 15 years. MSP now is firmly established within the UK with several pieces of primary legislation, marine planning policies and a suite of marine plans, both national and regionally, for onshore and offshore waters, all at various stages of implementation across the UK.

Since the formal introduction of MSP, it has positively altered the way in which the marine environment has been socially constructed. Therefore, the whence of this paper is that while there has been some success in bringing the marine environment to the attention of the public, with increasing scientific research, the introduction of the marine governance architecture and management frameworks, all of this has happened in a period of unprecedented change and uncertainty. The 'marine problem' lingers as both an environmental and an institutional one and it seems clear that we are no closer to identifying the appropriate intervention to say that we have appropriately and successfully socially reconstructed the marine environment.

More analysis is needed of how claims for the marine problem is constructed which are vital to understanding the current, and future, marine governance context and its relationship to other agendas (e.g. blue growth) and regimes (e.g. land use planning). The blue growth agenda promotes a commitment to achieving smart, sustainable and inclusive maritime growth and job creation. It is prevalent in many of the marine plans, with objectives such as 'sustainable development of productive activities' (DAERA 2018a) and 'sustainable development of marine resources' (Scottish Government 2015), serving to act as plans for developers. This did not feature heavily in the identified 'marine problem' in 2004 but the blue growth agenda has since intensified, adding additional economic pressures on the marine environment. Similarly, it is not clear how MSP relates seamlessly to land use planning. While there is emphasis in plans on the need for land-sea integration, how this is achieved in practice is still not clear. With more and more development taking place offshore (mostly in the form of renewable energy), there are still many parallel and significant development pressures onshore (through sub-stations and interconnectors). While in the early 2000 s, it was believed that Integrated Coastal Zone Management would offer an approach to solve this 'nearshore space' (Peel and Lloyd 2004); its lack of statutory basis created a vacuum in these areas O'Hagan and Ballinger 2010. A clear linear demarcation of where land use planning boundaries finish and where marine planning boundaries should start has emerged, often leading to duplication of administration. There is little holistic or aspirational incentive for these systems to work together at these locations, other than stating that public authorities must consider the land and sea interactions of proposals. However, the Welsh Government (2019) included direct references to the use of Shoreline Management Plans and emphasises a clear need for improved integration between terrestrial and marine planning.

It is clear that the marine problem is continually evolving and morphing, to be not only institutional and environmental one, but it might also now be considered a social, economic and spatial problem. Having developed the arguments of Peel and Lloyd (2004) through Hannigan's six prerequisites, we noted that there has been growing interest in marine social sciences (Bennett 2019; Shah 2020), but the pathways of including this evidence within policy remain a challenge. We saw the rise and role of social media platforms in promoting environmental problems (Krau and Chahal 2018), and we saw the role of celebrity through the dramatization (Boykoff and Goodman 2009), noting the surprising 'Attenborough effect' which sustains and focuses attention on the problem. We see that, while previously, the dramatization was around overfishing and pollution, the sustained public awareness (Monbiot 2018) has moved onto the marine plastic agenda (Stafford and Jones 2019) and their size and location. In terms of searching for an institutional sponsor, we saw a multitude of bodies forming, mostly in the form of government bodies. The whence of this paper has been to look at what has happened in the intervening years of Peel and Lloyd's seminal work; the whither is much more difficult to articulate.

The institutional frameworks have been created for seemingly integrated marine governance, yet in practice, we still see the same issues that were occurring previously such as piecemeal development, ad hoc silo sector-driven mentality, with objectives of short-term economic gain for developers. Indeed, it can be said that all of this has lead the marine problem to worsen. Using Hannigan's six prerequisites has shown that there is societal recognition of the marine problem in terms of the vulnerability of the marine environment. There is still much work to be done in finding an appropriate 
institutional sponsor. Once all the marine plans are implemented, it will become clear as to how MSP will 'officially' become practiced in the UK as a plan led activity. Peel and Lloyd (2004) concluded by saying that problem of the marine environment has barely scratched the surface; we propose that while much has been achieved since then, we are still treading water.

\section{Compliance with ethical standards}

Conflict of interest The authors declare that they have no conflict of interest.

Open Access This article is licensed under a Creative Commons Attribution 4.0 International License, which permits use, sharing, adaptation, distribution and reproduction in any medium or format, as long as you give appropriate credit to the original author(s) and the source, provide a link to the Creative Commons licence, and indicate if changes were made. The images or other third party material in this article are included in the article's Creative Commons licence, unless indicated otherwise in a credit line to the material. If material is not included in the article's Creative Commons licence and your intended use is not permitted by statutory regulation or exceeds the permitted use, you will need to obtain permission directly from the copyright holder. To view a copy of this licence, visit http://creativecommons.org/licenses/by/4.0/.

\section{References}

Allsopp, M. 2007. Oceans in peril, protecting marine biodiversity. Danvers, MA: Worldwatch Institute

Anderson, A. 2013. Together we can save the artic: Celebrity advocacy and the Rio Earth Summit 2012. Journal of Celebrity Studies 4 (3): 339-352. https://doi.org/10.1080/19392397.2013.831617

Anyanwu, P.E., Craig, P., Katikireddic, S.V. and Green, M.J. 2018. Impacts of smoke free public places legislation on inequalities in youth smoking update: study protocol for a secondary analysis. British Medical Journal 8 (3): 1-8. https://doi.org/10.1136/ bmjopen-2018-022490.

Bennett, N.J. 2019. Marine social sciences for the peopled sea. Coastal Management 47 (2): 244-252. https://doi.org/10.1080/08920753. 2019.1564958.

Boykoff, M.T. and Goodman, M.K. 2009. Conspicuous redemption? Reflections on the promises and perils of the 'celebritization' of climate change. Geoforum 40 (3): 395-406.

Boyes, J.S. and Elliot, M. 2014. Marine legislation - the ultimate 'horrendogram': international law, European directives and national implementation. Marine Pollution Bulletin 86 (1-2): 39-47.

Boyes, J.S. and Elliot, M. 2016. Brexit: The government horrendogram just got more horrendous. Marine Pollution Bulletin 111 (1): 41-44.

Brown, C., Walpole, M., Simpson, L. and Tierney, M. 2011. Introduction to the UK National Ecosystem Assessment. In The UK National Ecosystem Assessment Technical Report. Cambridge: UK National Ecosystem Assessment, UNEP-WCMC.

Bull, S.K. and Laffoley, D. 2003. Networks of Protected Areas in the Maritime Environment (report for the review of marine nature conservation and the marine stewardship process stakeholder workshop, London, 19 June 2003), (English nature research report, no. 537), Peterborough, English Nature.

Burr, V. 2003. Social constructionism. 2nd ed. London: Routledge.
Canning, R. 2003. The elements of marine spatial planning: key drivers and obligations in Earll, R. (ed) Spatial Planning in the coastal and marine environment: next steps to action. CoastNET conference, 1 October 2003, SOAS, University of London.

Convention on Biological Diversity. 2019. Aichi Biodiversity Targets < https://www.cbd.int/sp/targets > [19th June 2019].

Department of Agriculture, Environment and Rural Affairs. 2018a. Draft Marine Plan for Northern Ireland, <https://www.daerani.gov.uk/ sites/default/files/consultations/daera/Marine\%20Plan\%20for\% $20 \mathrm{NI} \% 20$ final $\% 2016 \% 2004 \% 2018 . \mathrm{PDF}>$ [accessed on 29th October 2018].

Department of Agriculture, Environment and Rural Affairs. 2018b. Northern Ireland Environmental Statistics Report. Belfast: DAERA.

Department of Agriculture, Environment and Rural Affairs. 2019. Northern Ireland Environmental Statistics Report. Belfast: DAERA.

Department of the Environment. 2006. Towards an integrated coastal zone management strategy for Northern Ireland < https://www. daera-ni.gov.uk/publications/towards-integrated-coastal-zonemanagement-strategy-northern-ireland-2006-2026> [Accessed $29^{\text {th }}$ May 2019].

Department for Environment, Food and Rural Affairs. 2001. Safeguarding our seas: a strategy for the conservation and sustainable development of our marine environment, London, DEFRA.

Department for Environment, Food and Rural Affairs. 2002. Seas of change: consultation paper. London: DEFRA.

Department for Environment, Food and Rural Affairs. 2019. Marine strategy part one UK updated assessment of good environmental status, consultation document, May 2019, <https://consult.defra. gov.uk/marine/updated-uk-marine-strategy-part-one/supporting documents/UKmarinestrategypart1 consultdocumentfinal.pdf> [Accessed $13^{\text {th }}$ February, 2020].

Derraik, J.G. 2002. The pollution of the marine environment by plastic debris: a review. Marine Pollution Bulletin 44: 842-852.

Earth's Oceans Foundation. 2019. Challenge, < https://earthsoceans. foundation/about-eo/challenge $>$ [Accessed $30^{\text {th }}$ August, 2019].

Erdogan, B.Z. 1999. Celebrity endorsement: a literature review. Journal of Marketing Management 15 (4): 291-314.

European Commission. 2007. Integrated Maritime Policy, < https:/ec. europa.eu/maritimeaffairs/policy_en $>$ [Accessed $9^{\text {th }}$ June 2019].

European Commission. 2008a. Marine strategy framework directive, EC $<\mathrm{http}$ ://ec.europa.eu/environment/marine/eu-coast-and-marinepolicy/marine-strategy-framework-directive/index_en.htm $>\left[19^{\text {th }}\right.$ June 2019].

European Commission. 2008b. Roadmap for maritime spatial planning: achieving common principles in the $E U$, $<\mathrm{https}$ ://eur-lex.europa.eu/ LexUriServ/LexUriServ.do?uri=COM:2008:0791:FIN:EN:PDF > $\left[19^{\text {th }}\right.$ June 2019].

European Commission. 2012. Blue Growth Strategy available from https://eurlex.europa.eu/legal-content/EN/ALL/?uri=CELEX: 52012DC0494. Accessed 13 Mar 2020.

European Parliament. 2014. Directive 2014/89/EU of the European parliament and of the council of 23 July 2014 establishing a framework for maritime spatial planning, <https://www.eea.europa.eu/policydocuments/directive-2014-89-eu-maritime $>$ [Accessed 18th June 2019]

Fearnly-Whittingstall, H. 2010. Hugh's Fish Fight, < https://www. rivercottage.net/campaigns/hughs-fish-fight $>$ [accessed 19th June 2019].

Ferreira, S., Convery, F. and McDonnell, S. 2007. The most popular tax in Europe? Lessons from the Irish plastic bag levy. Environmental and Resource Economics 38 (1): 1-11.

Flannery, W., O'Hagan, A.M., O'Mahony, C., Ritchie, H. and Twomey, S. 2015. Evaluating conditions for transboundary marine spatial planning: challenges and opportunities on the island of Ireland. Marine Policy 51: 86-95. 
Flannery, W. and Ellis, G. 2016. Exploring the winners and losers of marine environmental governance. Planning Theory and Practice 17 (1): 121-151.

Flannery, W., Clarke, J. and Mcateer, B. 2018. Politics and power in marine spatial planning, in Maritime Spatial Planning Past Present Future, (eds) J. Zaucha and K. Gee, Palgrave McMillan, Switzerland.

Fletcher, S., Jefferson, R., Glegg, G., Rodwell, L. and Dodds, W. 2014. England's evolving marine and coastal governance framework. Marine Policy 45: 261-268.

Geyer, R., Jambeck, J. and Law, K.L. 2017. Production, use and the fate of all plastics ever made. Science Advances 3 (7): 1-5. https://doi. org/10.1126/sciadv.1700782.

Gilbert, A.J., Alexander, K., Sardá, R., Brazinskaite, R., Fischer, C., Gee, K., Jessopp, M., Kershaw, P., Los, H.J., Morla, D.M.A.R.C.H., O’Mahony, C., Pihlajamäki, M., Rees, S. and Varjopuro, R. 2015. Marine spatial planning and good environmental status: a perspective on spatial and temporal dimensions. Ecology and Society 20 (1): 64.

Global Citizen. 2019. The Attenborough effect is causing plastic pollution to plummet, < https://www.globalcitizen.org/en/content/ attenborough-effect-plastics/ $>$ [Accessed $19^{\text {th }}$ June 2019].

Government Office for Science. 2017. FORESIGHT Future of the Sea. London: A report from the Government Chief Scientific Advisor.

Greenebaum, J. 2015. Veganism, identity and the quest for authenticity. Food and Cultural Society 15: 128-144.

Hannigan, J.A. 1995. Environmental sociology: a social constructionist perspective, London, Routledge.

Hannigan, J.A. 2006. Environmental sociology: a social constructionist perspective. 2nd ed. London: Routledge.

HM Government. 2011. UK marine policy statement. London: The Stationery Office.

Hull, S. 2015. Marine planning in the UK. Making a Difference, ABPMer, Marine Environmental Research, Southampton.

Ibarra, P.R. and Kitsuse, J.I. 1993. Vernacular constituents of moral discourse: an interactionist proposal for the study of social problems, pp. 21-54 in Constructionist Controversies. In Social Problems Theory (Social Problems and Social Issues), ed. D.R. Loseke and J. Best. Hawthorne: Aldine de Gruyter.

Jay, S. 2010. Built at sea: marine management and the construction of marine spatial planning. The Town Planning Review 81 (2): 173191

Jefferson, R., Laffoley, D. and Richards, J. 2015. Public perceptions of the UK marine environment. Marine Policy 43: 327-337.

Joint Nature Conservation Committee. 2002. The Irish sea pilot. Peterborough: Report to DEFRA by JNCC.

Jones, S. 2002. Social construction and the environment through the quagmire. Global Environmental Change G12 (4): 247-251.

Kelly, C., Ellis, G. and Flannery, G. 2019. Unravelling persistent problems to transformative marine governance. Frontiers in Marine Science 6 (23): 1-15.

Kelly, C., Ellis, G. and Flannery, W. 2018. Conceptualising change in marine governance: learning from transition management. Marine Policy 95: 24-35.

Kidd, S. and Ellis, G. 2012. From the land to sea and back again? Using terrestrial spatial planning to understand the process of marine spatial planning. Journal of Environmental Policy and Planning 14 (1): 49-66.

Knott, D. 2019. Introduction to Belfast Harbour Commissioners, Presentation given to the Irish Sea maritime forum on $5^{\text {th }}$ June 2019, Belfast.

Kratzig, S. and Warren, B. 2014. Using interactive web tools in environmental planning to improve communication about sustainable development. Sustainability 6: 236-250.
Krau, A. and Chahal, H. 2018. The role of social media in increasing environmental awareness', Journal of Arts, Science and Commerce, IX (1), pg. 19-27.

Lloyd, M.G. 2008. Planning reform in Northern Ireland independent report to the minister for the environment. Liverpool: University of Liverpool.

Lundahl, O. 2018. Dynamics of positive deviance in destigmatisation, celebrities and the media in the rise of veganism. Consumption, Markets and Culture 1-13. https://doi.org/10.1080/10253866. 2018.1512492.

Northern Ireland Affairs Committee. 2018. Brexit and Northern Ireland Fisheries Document. House of Commons 878.

Northern Ireland Office. 1998. The Belfast Agreement, <https:/www. gov.uk/government/publications/the-belfast-agreement $>$ [accessed on 29.10.2018].

Maes, F., Calewaert, J, Schrivers, J., van Lancker, V, Vanhull, A., Abeele, P., Verfaille, E. Derous, S., Volckaert, A., Degraer, S. and Wachter,B. 2007. Gaufre: towards a spatial structure plan for sustainable development management of the Belgian part of the North Sea, in Calewaert, J and Maes, F. (eds) Science and Sustainable Management of the North Sea, Academic Press, Gent

McClelland, A. 2014. Contesting destruction, constructing heritage: the social construction of architectural heritage values in Belfast, circa 1960-1989. Ulster University.

McElduff, L. and H. Ritchie. 2018. Coastal zone management in the United Kingdom. In Regulating Coastal Zones: International Perspectives, ed. R. Alterman and C. Pellach. London: Routledge.

McGowan, L. 2011. Practice and prospects for integrated coastal zone management (ICZM) in the UK : improving non-statutory coastal governance through collaboration. (PhD Thesis), The University of Liverpool

McKinley, E. and Fletcher, S. 2010. Individual responsibility for the oceans? An evaluation of marine citizenship by UK marine practitioners. Ocean and Coastal Management 53: 379-384.

Monbiot, G. 2018. David Attenborough has betrayed the world he loves, $<$ https://www.theguardian.com/commentisfree/2018/nov/07/davidattenborough-world-environment-bbc-films $>$ [accessed on 13th February, 2020].

O'Hagan, A.M. and Ballinger, R. 2010. Implementing integrated coastal zone management in a national policy vacuum: local case studies from Ireland. Ocean and Coastal Management 53 (12): 750-759.

Pahl, S., Wyles, K.J. and Thompson, R.C. 2017. Channelling passion for the ocean towards plastic pollution. Natural Human Behaviour 1: 697-699.

Peel, D. and Lloyd, M.G. 2004. The social reconstruction of the marine environment: towards marine spatial planning. The Town Planning Review 75 (3): 359-378.

Potts, T., Pita, C., O'Higgins, T. and Mee, L. 2016. Who cares, European attitudes towards marine and coastal environments. Marine Policy 72: 59-66.

Ritchie, H. 2014. Understanding emerging discourses of marine spatial planning in the UK. Land Use Policy 38: 666-675.

Ritchie, H. and Ellis, G. 2010. A system that works for the sea. Journal of Environmental Planning and Management 53 (6): 701-723.

Ritchie, H. and Flannery, W. 2017. Advancing integrated marine spatial planning in Northern Ireland. In Planning Law and Practice in Northern Ireland, ed. S. Mckay and M. Murray. London: Routledge.

Rittle, H.W.J. and Webber, M.M. 1973. Dilemmas in a general theory of planning. Policy Sciences 4 (2): 155-169.

Russ, G.R. and Zeller, D.C. 2003. From Mare Liberum to Mare Reservarum. Marine Policy 27 (1): 75-78.

Russell, M. 2010. A Sea Change in the marine aggregates sector, British Marine Aggregate Producers Association < https://www.agg-net. $\mathrm{com} /$ resources/articles/marine-aggregates/a-sea-change-for-themarine-aggregate-sector $>$ [accessed 19th June 2019]. 
Sea Shepherd. 2018. Operation clean waves: ocean clean-up < https:// seashepherd.org/campaigns/clean-waves/ $>$ [Accessed $19^{\text {th }}$ June 2019].

Schwandt, T. 2000. Three epistemological stances for qualitative inquiry. Interpretivism, hermeneutics and social constructionism. In Handbook of 28 Qualitative Research, ed. N.K. Denzin and Y.S. Lincoln, 2nd ed., 189-213. London: Sage.

Scottish Executive. 2002. Assessment of the effectiveness of local coastal management partnerships as a delivery mechanism for integrated coastal zone management (social research, countryside and natural heritage, research findings 23). Scottish Executive: Edinburgh.

Scottish Government. 2015. Scotland's National Marine Plan, available from https://www.gov.scot/publications/scotlands-national-marineplan/. Accessed 13 Mar 2020.

Shah, H. 2020. Global problems need social science, Nature, 577. Worldview.

Stafford, R. and Jones, P.J.S. 2019. Viewpoint: ocean plastic pollution - a convenient but distracting truth. Marine Policy 103: 1870-1191.

Thompson, R. 2017. Environment: a journey on plastic seas. Nature 547 (2017): 278.

Tyldesley, D. 2004. Making the case for marine spatial planning in Scotland, Edinburgh, RSPB, Scotland and RTPI in Scotland.

UK Government 2009. Our seas: a shared resource, high level marine objectives, < https://www.gov.uk/government/publications/our- seas-a-shared-resource-high-level-marine-objectives $>$ [Accessed $23^{\text {rd }}$ August 2019].

United Nations. 1982. United Nations Convention on the Law of the Sea. Montego Bay: UN.

United Nations. 2015. United Nations Climate Change Conference Paris, $<\mathrm{http}$ ://www.cop21 paris.org/about/cop21 > [Accessed $19^{\text {th }}$ June 2019].

Welsh Government. 2019. Welsh National Marine Plan available from https:/gov.wales/welshnational-marine-plan-document. accessed 13.3.2020

Wildlife Trust. 2019. Living Seas Project < https://www.wildlifetrusts. org/about-us/vision-and-mission/living-seas $>$ [Accessed $23^{\text {rd }}$ August].

WWF. 2002. North sea cod stocks in danger of collapse, < https://www. wwf.org.uk/updates/north-sea-cod-stocks-verge-collapse $>$ [Accessed 19 ${ }^{\text {th }}$ June 2019].

Xanthos, D. and Walker, T.R. 2017. International policies to reduce plastic marine pollution from single-use plastics (plastic bags and microbeads): a review. Marine Pollution Bulletin 118: 17-12 6.

Publisher's note Springer Nature remains neutral with regard to jurisdictional claims in published maps and institutional affiliations. 